\title{
MEDIASTENIN MALIGN LENF NODU HASTALIKLARI
}

\author{
Serdar ONAT \\ Dicle Üniversitesi Tıp Fakültesi, Göğüs Cerrahisi Anabilim Dalı, Diyarbakır, Türkiye \\ e-posta: onatserdar21@hotmail.com \\ doi:10.5152/tcb.2011.17
}

Tümörle ilişkili morbidite ve mortalitenin en büyük sebebi metastazdır. Lenf nodları tümör progresyonunun kontrolünde önemli role sahiptirler. Mediasten lenf akımı açısından oldukça zengin bir alandır. Metastatik akciğer kanseri en sık malign adenopati nedenidir. Kısa çapı $1 \mathrm{~cm}$ den büyük lenf nodları akciğer kanser evrelendirmesinde potansiyel anormal lenf bezi olarak değerlendirilir. Malign hastalık durumunda bazen büyüyen lenf nodları maligniteye bağlı olmayıp postobstruktif pnömoniye bağlı inflamasyon sonucu oluşurlar. Özellikle skuamöz hücreli kanserlerde bu durum daha sık görülür. Naruke ve ark. 1978 yılında mediastendeki lenf istasyonlarını mediastendeki anatomik yapılara ve bronş ağacına göre sınıflandıran yazılarını yayınladılar (1). Mediastendeki lenf nodu istasyonlarını 1-9'a kadar, hiler, interlober ve intrapulmoner istasyonlar 10-14 arasında numaralandırdılar. ATS 1981 yılında farklı bir lenf nodu haritası yayınladı (2). 1997'de Mountain ve Dresler, Naruke ve ATS'nin haritalarını uzlaştıran bir harita yayınladılar (3). Akciğer Kanser Evrelendirmesinin 7. basımı bu haritalar ışığında evrelendirilmiştir (4).

Mediastendeki lenf nodları, toraks içi patolojilerin tutulum yeri olduğu gibi, aynı zamanda toraks dişı patolojiler de de mediasten lenf nodları tutulumu olabilir.

İnsanlarda solid kanserlerde prognozu belirleyen en önemli faktör lenf nodu tutulumudur (5).

Yapılan çalışmalarda primeri belli olmayan, metastazla başvurulan kanser oranının \%5-7 arasında olduğu belirtilmiştir $(6,7)$. Ayrıca lenf nodları tüm vakaların \%31-46 metastaz oranıyla en sık metastaz yeri olmuştur (8). Üç büyük mediastinoskopi serisinde mediastinal lenf nodlarının \%11-16'sının okkült tümörlerden kaynaklandığı tespit edilmiştir (9). Kaynağı bilinmeyen metastazlı hastalarda survey ortalama 6 ay olarak bulunmasına rağmen daha uzun survey cerrahi içeren tedavilerde mümkün olmuştur (10). Primeri bilinmeyen torasik lenf nodu tutulumu olan vakaları inceleyen bir çalışmada, intrapulmoner tutulum oranı \%25 bulunmuşken, mediastinal tutulum \%75 oranında tespit edilmiştir (11). Mediasteni tutan bu patolojilerin kötü diferansiye veya undiferensiye olduğu bildirilmiştir.

Infradiyafragmatik kanserler mediasten tutulumu yapabilir (12). Ayrıca radyolojik görünümü lenfomaya benzeyen iyi diferensiye adenokarsinomlara da ön ve orta mediastende tanı konulmuştur. Ayrıcı tanı için histopatolojik inceleme ve immünhistokimya boyaları kullanılmasına rağmen, primer kaynak bazen tespit edilemez. Bunun için farklı teoriler öne sürülmüştür. Bazıları primer tümörün mevcut radyolojik incelemeyle tespit edilemediğini, takiplerde asıl patolojinin ortaya çıktığını savunurken, bazısı primer tümörün daha önce farkına varımadan çıkarımış olabileceğini, diğer grupta primer tümörün kendiliğinden ortadan kalkabileceğini savunmuştur (13).

Papiller tiroid karsinomu olan 241 hastanın incelenmesinde \%4.5'inde mediastinal lenf nodu tutulumu saptanmıştır (14). Metastatik prostat karsinomlu hastalarda aksiller lenf nodu metastazı ve mediastinal lenf nodu metastazı tespit edilmiştir (15). Renal, meme, testiküler kaynaklı tümörler ve melanom da nadiren mediastinal lenfadenopati yapar.

Küçük hücreli kanserde de mediasten tutulumu yaygın ve bazen primer akciğerdeki lezyondan büyük olabilir (Resim 1).

\section{Mediastinal Lenfoma}

Tek izole mediasten kitlesi şeklinde karşımıza çıktıkları gibi pulmoner parankimal infiltrasyon veya adenopati şeklinde de görülebilirler. Kavitasyon veya kistik 


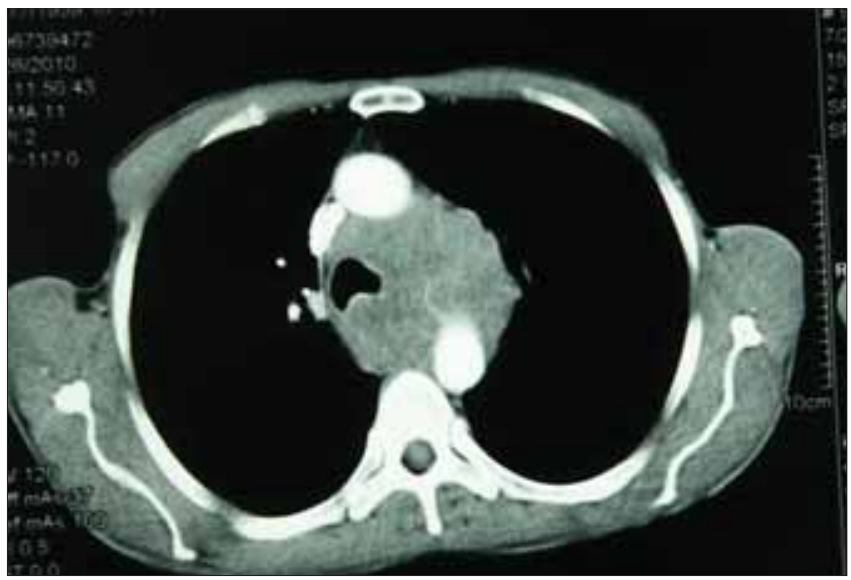

Resim 1. Mediasten lenf nodu tutulumu yapan small cell ca

dejenerasyon nadiren görülür. Tümör, göğüs duvarı ve çevre organları tutabilir.

Lenfomalar, tüm mediastinal kitlelerin \%15'ini kapsar (16). Lenfomaların doğru tanınıp uygun tedavi edilmeleri için sınıflandırılma ihtiyacı oluşmuştur. Farklı zamanlarda farklı sınıflandırmalar kullanılmışıı. En sık ve en son 2008 yilında güncellenen haliyle WHO sınıflandırması kullanılmaktadır (Tablo 1) (17, 18). Lenfomaların üçte biri Hodgkin, üçte ikisi nonhodgkindir. Lenfomaların büyük çoğunluğuna ön ve orta mediastende rastlanır. Çocukluk yaş grubunda ön mediasten kitlelerin \%45'i lenfomadır.

Hodgkin tanılı hastaların \%60'ında tanı anında mediastende hastalık mevcutken, \%3'ünde hastalık mediastenle sınırlıdır. Non-hodgkin lenfomaların \%20'si mediasteni tutar ve $<\% 10$ 'u mediastenle sınırlıdır.

\section{Hodgkin Lenfoma}

1832 yılından beri tanınan Reed-Sternberg hücrelerinin histolojik olarak görülmesi ile tanı konur. Diğer B-hücreli lefomalardan ayrılır. Non-hodgkine göre yıllardır görülme sıklığı stabil gitmektedir (19). Medeiros 15-34 yaş arasını ve 55 yaştan sonrasını insidansın pik yaptığı gruplar olarak belirlemiştir (20). Genel olarak cinsiyet ayrımı olmamasına rağmen, erkeklerde ölüm oranı daha yüksek bulunmuştur. Hodgkin lenfoma tüm lenfomaların yaklaşık \%10'nu ve tüm kanserlerin \%0.6'sını kapsar (21). Klasik Hodgkin Lenfoma (kHL) ve Noduler lenfositik predominant Hodgkin Lenfoma (NLPHL) diye iki gruba ayriır. kHL, noduler skleroz, miks sellüler, lenfositten zengin ve lenfositten yoksun olmak üzere dört alt gruba ayrilır. NLPHL nadiren mediasteni tutar.

Noduler skleroz HL ekonomisi iyi olan toplumlarda genç erişkinlerde sık görülürken, ekonomik olarak geri toplumlarda miks sellüler tip çocuklar ve yetişkinlerde sık görülür. Gelișmekte olan ülkelerde görülme sıklıkları aynıdır. Avrupa ve Amerika'da görülme oranları şu şekilde sıralanabilir (22), noduler skleroz; \%70, mix sellüler tip \%20-25, lenfositten zengin tip $\% 5$ ve lenfositten yoksun tip \%1'in altında. Ebstein-Barr virüsüyle, infeksiyöz mononukleozis hikayesi olanlarda Hodgkin lenfoma daha sık tespit edilmişir (23). Aspirinin riski azalttığı, buna karşın sigaranın riski arttırdığı iddia edilmiştir $(24,25)$. İmmun yetmezliklerde ve HIV enfeksiyonlarda da HL insidansı 5-25 kat arasında artmıştır (26).

Büyük çoğunluk boyun ve supraklavikuler bölgede ağrısız lenfadenopati ile başvurur. Mediastinal tutulum vardırve büyük boyutlara ulaşabilirler. Subdiyafragmatik tutulum nadirdir (Resim 2a, b). Semptomlar malign bir hastalıktan ziyade enfeksiyöz bir hastalıkla uyumludur. Rutin çekilen akciğer grafisinde mediastinal kitle görülür. Kitle tamamen asemptomatik kalabileceği gibi, göğüs ağrısı, nefes darlığı, bası hissi ve öksürük gibi nonspesifik semptomlara da yol açabilir. Bulky tutulum hariç perikardiyal ve plevral efüzyon olağan değildir. Vena kava superior sendromu nadiren oluşur. Bulky tutulum kötü bir prognostik faktördür. Revise edilen Ann-Arbor evrelendirmesinde, bulky mediastinal tutulum, kitlenin çapının, mediastenden göğüs duvarına genişliğin üçte birinden fazla olması şeklinde tanımlanmıştır. Ateş önceleri akşamları olurken zamanla daha ciddi ve yaygın hal alır. Hastaların yaklaşık üçte birinde halsizlik, yaygın kaşıntı, kilo kaybı, ve gece terlemesi görülür. Ateş, kilo kaybı ve gece terlemesi lenfoma için klasik 'B' semptomları olarak adlandırılır. Alkol alımından hemen sonra oluşan ağrı, \%10 civarında görülür ve $\mathrm{HL}$ için bir hayli spesifiktir. Düşük serum albumin değeri, anemi, erkek cinsiyet, evre 4 hastalık, yaş $>45$,, lökositoz (>15.000), ve lenfopeni, prognoza kötü etki eden faktörler olarak bilinir. Santral sinir sistemini çok nadir (\%0.02-0.5) tutar. Nefrotik sendrom paraneoplastik sendrom sonrası görülebilir.

Uygun tanı için, klasik histolojik incelemeye ek olarak sitogenetik, immunuassay ve immunofenotipik incelemeye intiyaç vardır. Bunun için uygun büyüklükte dokunun incelenmesi gerekir. Küçük biyopsilerle benign- malign ayrımı ve alt sıflandırma imkanı yoktur. İnce iğne aspirasyon biyopsileri ve core biyopsi ile uygun hücrelere ulaşmak her zaman mümkün değildir. Periferik lenf nodu yoksa, mediastinoskopi, mediastinostomi, VATS ve hatta gerekirse torakotomi ile biyopsi alınmalıdır (19).

Histolojik tanı konduktan sonra klinik evrelendirme yapılmalıdır. Tam kan, serum LDH (prognostik bir faktördür), karaciğer ve böbrek fonksiyon testleri çallşılmalıdır. Radyolojik evrelendirme için, tüm vücut CT ve kemik iliği biyopsisine ek olarak PET'te eklenmiştir. Kemik iliği biyopsisi daha ileri evrelerde, B sempto- 
Tablo 1. Hemopoetik ve lenfoid doku tümörlerinin yeni sınıflandırması

Swerdlow, SH, Campo, E, Harris, NL, et al. (Eds). World Health Organization Classification of Tumours of Haematopoietic and Lymphoid Tissues, IARC Press, Lyon 2008

\section{Miyeloid Neoplasmlar}

Akut miyeloid lösemi

Miyelodisplastik sendromlar

Miyeloproliferatif neoplasmlar

Kronik miyelogenöz lösemi

Kronik nötrofilik lösemi

Polisitemi vera

Essensiyel trombositopeni

Primer miyelofibrozis

Kronik eozinofilik lösemi

Mastositozis

Miyelodisplastik/miyeloproliferatif sendromlar

Kronik miyelomonositik lösemi

Atipik kronik miyelogenöz lösemi BCR-ABL-1 negatif

Juvenil monositik lösemi

Lenfoid Neoplasmlar

Prekörsör lenfoid lösemiler

Prekörsör B-hücreli lenfoblastik lösemi/lenfoma

Prekörsör T-hücreli lenfoblastik lösemi/lenfoma

Mature B-hücreli neoplasmlar

Mantle hücreli lenfoma

B-hücreli prolenfositik lösemi

Kronik lenfositik lösemi/ küçük lenfositik lenfoma

Folliküler lenfoma

Diffüz büyük B-hücreli lenfoma

Burkitt lenfoma

Marginal zone B-hücreli lenfoma

Hairy cell lösemi

Lenfoplasmasitik lenfoma

Plasma hücreli lenfoma

$\mathrm{AL}$ (primer) amiloidoz

Hodgkin lenfoma

Noduler lenfosit predominant Hodgkin lenfoma

Klasik Hodgkin lenfoma

Noduler sklerozan klasik

Miks sellüler klasik

Lenfositten zengin klasik

Lenfositten yoksun klasik

Mature T-hücreli veya NK hücreli neoplasmlar

T- hücreli prolenfositik lösemi

Periferal T-hücreli lenfoma

Anaplastik büyük hücreli lenfoma

Primer kutanöz periferal T-hücreli lenfoma

Adult T-hücreli lenfoma/lösemi

T-hücreli büyük granuler lenfositik lösemi

Natural killer hücreli büyük granüler lenfosit lösemi

Agresif nötral killer hücreli lösemi

Myeloid ve lenfoid differansiyasyonlu neoplasmlar

Eozinofili ve PDGFRA, PDGFRB veya PGFR 1 anormalliği olan miyeloid/lenfoid neoplasmlar

Belirsiz serili akut lösemiler

Histiyositik / dendritik neoplasmlar 


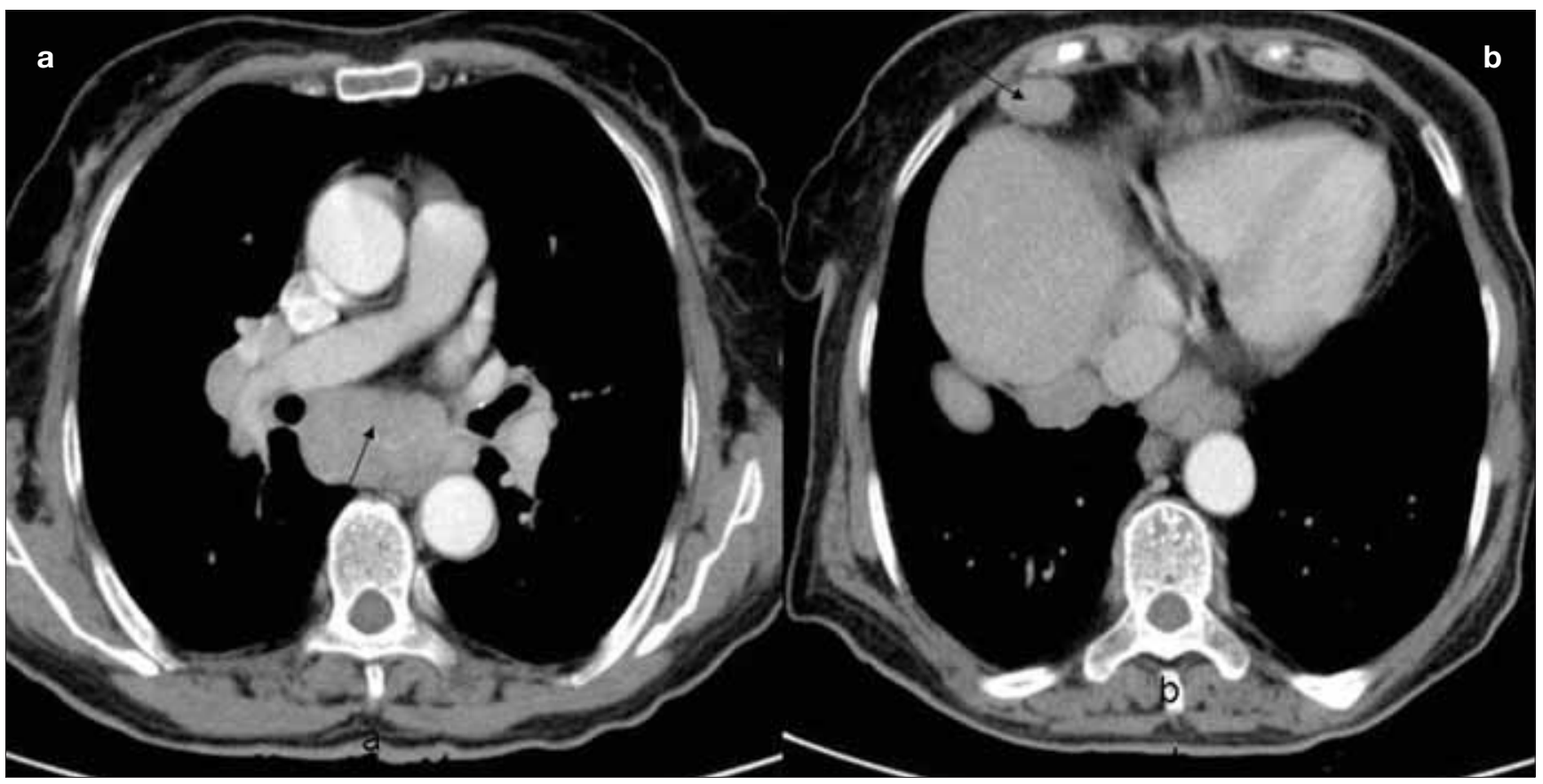

Resim 2. Hodgkin lenfomalı hastaya ait lenf nodu tutulumu

Tablo 2. Ann Arbor evreleme sistemi; Cotswolds modifikasyonu

Evre I: Tek lenf nodu bölgesi tutulmuş (örnek, servikal, aksiller,inguinal, mediastinal)

Evre II: Diyafragmanın aynı tarafında iki veya daha fazla lenf nodu bölgesi tutulmuş, tüm mediasten tek bölge sayılırken hiler bölge farklı grup sayılır

Evre III: Diyafragmanın her iki tarafındaki bölgeler tutulmuş. Evre III-1 veya III-2 diye ikiye ayrılır. Evre III-1, dalak,splenik hiler, çöliyak veya portal node tutulumunu gösterirken, III-2, paraaortik, inguinal,mesenterik veya iliak tutulumu gösterir

Evre IV: Difüz veya disemine ekstranodal bir veya daha fazla organ tutulumu veya doku tutulumu 'E' olarak belirtilir. Lenf nodu tutulumu olabilir veya olmayabilir

Ayrıca vakalar, sistemik semptomlarına göre, 'A'yok, 'B' var diye tespit edilir

Yaygın ekstranodal tutulum Evre IV olarak adlandırılır

$X$ bulky hastalığı gösterir

Lister, TA, Crowther, D, Sutcliffe, SB, et al, J Clin Oncol 1989; 7:1630

mu olanlarda ve kan tetkiklerinde kemik iliği tutulum şüphesi olanlarda yapılması önerilir (27). Yıllar önce rutin yapılan laparatomi ve splenektomi, ancak sınırlı seçilmiş vakalara uygulanmalıdır. Minimal rezidüel ve mikroskopik hastalık haricinde FDG PET oldukça duyarlıdır. PET'in kullanımı gallium-67 sintigrafisinin kullanımını azaltmıştır.

Tedavi için Ann Arbor sınıflandırması ve Cotswolds revizyonu kullanılır, (Tablo 2) (28). Lenf nodu örneklemesi ve splenektomi "patolojik evrelendirme"yi kapsarken, fizik muayene ve radyolojik inceleme "klinik evrelendirme" adını alır. Radyolojik tekniklerin gelişmesi ve kemoterapinin yaygın etkin kullanımı arttıkça patolojik evrelendirmeye intiyaç azalmıştır. Erken evreler hariç, kemoterapi Hodgkin lenfomanın temel tedavisi haline gelmiştir.
Evre IA -IIA'ya kadar erken evrelerde kemoterapi ve etkilenen alana uygun radyoterapi güncel tedavi olarak yerini korumaktadır (29). Büyük mediastinal lenfadenopati, dört veya fazla lenf nodu bölgesinin tutulumu, yaşın 50'den büyük olması, veya B semptomlarının olması ve sedimantasyonun yüksek olması kötü prognoz kriteri olarak bulunmuştur (30). Kemoterapi rejimi olarak MOPP (meclorethamine, vincristine, procarbazine, prednisone) veya ABVD (doxorubicin, bleomycin, vinblastine, dacarbazine) kullanılır (29, 31). Erken evrede tek başına kemoterapi sadece radyoterapi için kontrendikasyon olanlara ve radyoterapi istemeyenlere uygulanmalıdır (32).

Ileri evrelerde kemoterapi temel tedavidir. ABVD, MOPP, Stanford V (doxorubicin, vinblastine, mechlorethamine, vincristine, bleomycine, etoposide, predni- 
sone) veya BEACOPP (bleomycine, etoposide, doxorubicin, cyclophoshamide, vincristine, procarbazine ve prednisone) kemoterapi protokolleri kullanılır. Canellos ABVD ile 10 yıllık \%60 survey saptamışken MOPP ile \%40 sağ kalım elde etmiştir (33). ABVD infertilite ve sekonder malignensileri azaltırken, kardiyak ve pulmoner toksisiteyi artırmıştır. ABVD şu an için en fazla önerilen tedavi seçeneğidir.

Relaps ve tedaviye direnç durumunda yüksek doz kemoterapi ve otolog hematopoetik hücre transplantasyonu önerilir (34).

Hodgkin lenfomada tedaviden 15 yıl sonra ikinci kanser oranı 13 kez artmıştır (35). En sık görülen ikinci kanserler; nonlenfoblastik lösemi, non-hodgkin lenfoma ve solid tümörlerdir (35).

Radyoterapi sonrası kardiyak aritmiler, koroner arter hastalıkları, perikardit, myokardit, perikardiyal efüzyon saptanmıştır (36). İnfertilite ABVD tedavisine geçildikten sonra azalmıştır.

\section{Non-Hodgkin Lenfoma}

\section{Primer Mediastinal B-Hücreli Lenfoma}

Primer mediastinal B-hücreli lenfoma, difüz büyük $B$ hücreli non-hodgkin lenfomanın bir alt grubudur ve daha çok otuzlu yaşlarda görülür. İntratimic B-hücre populasyonundan köken alır (36). Kadınlarda daha fazla görülür. Patolojik olarak diğer difüz büyük B-hücreli lenfomadan ayrımı zor olmakla beraber baş- vuru kliniği tamamen farklıdır. Ön ve üst mediasteni hızıca dolduran etraf dokuları saran kitle ile karşımıza çıkarlar (Resim 3a, b). Mediastene bası semptomlarından dolayı erken tanı konulur. İlk başvuru anında vakaların \%30'unda vena kava sendromu görülür. Frenik sinir invazyonu yapıp, bu iki taraflı olduğunda solunum yetmezliğine yol açabilir. Disfaji, kısıklığı, kısıklılığı, kadınlarda meme salgısının artması, ateş, gece terlemesi, kilo kaybı (B semptom), göğüs ağrısı ve öksürük görülebilir (19). B-semptomları vakaların üçte birinde görülür. Tüm NHL içinde $\% 5$ oranında görülür (37). Diğer lenfomaların aksine kromozomal bozukluk veya molekuler markır bulunamamıştır.

Tanı anında supraklavikular bölgede tümör palpe edilebilir. Tümör sıklıkla akciğer, plevra ve perikardı invaze eder. Kemik iliği tutulumu ve ekstratorasik tutulum sık değildir. Rekürens anında beyin, karaciğer ve böbreğe yayılım görülebilir (38).

Tanı için, Hogdkin lenfomada olduğu gibi uygun büyüklükte bir dokunun alınıp, histolojik, immunofenotipik ve moleküler çalışmanın yapılması gerekir. Evrelendirme yapılmalıdır. Plevral veya perikariyal effüzyonlar, lenfomatoz invazyon veya lenfatik dönüşün engellenmesi sonucu oluşur.

Evrelelendirme ve takipte, PET yaygın olarak kullanılmaya başlanmıştır. PET'in negatif prediktif değeri \%85 olarak bulunmuştur. Yanlış pozitif oranları \%20-30 arasında olması devam eden problemler arasındadır.

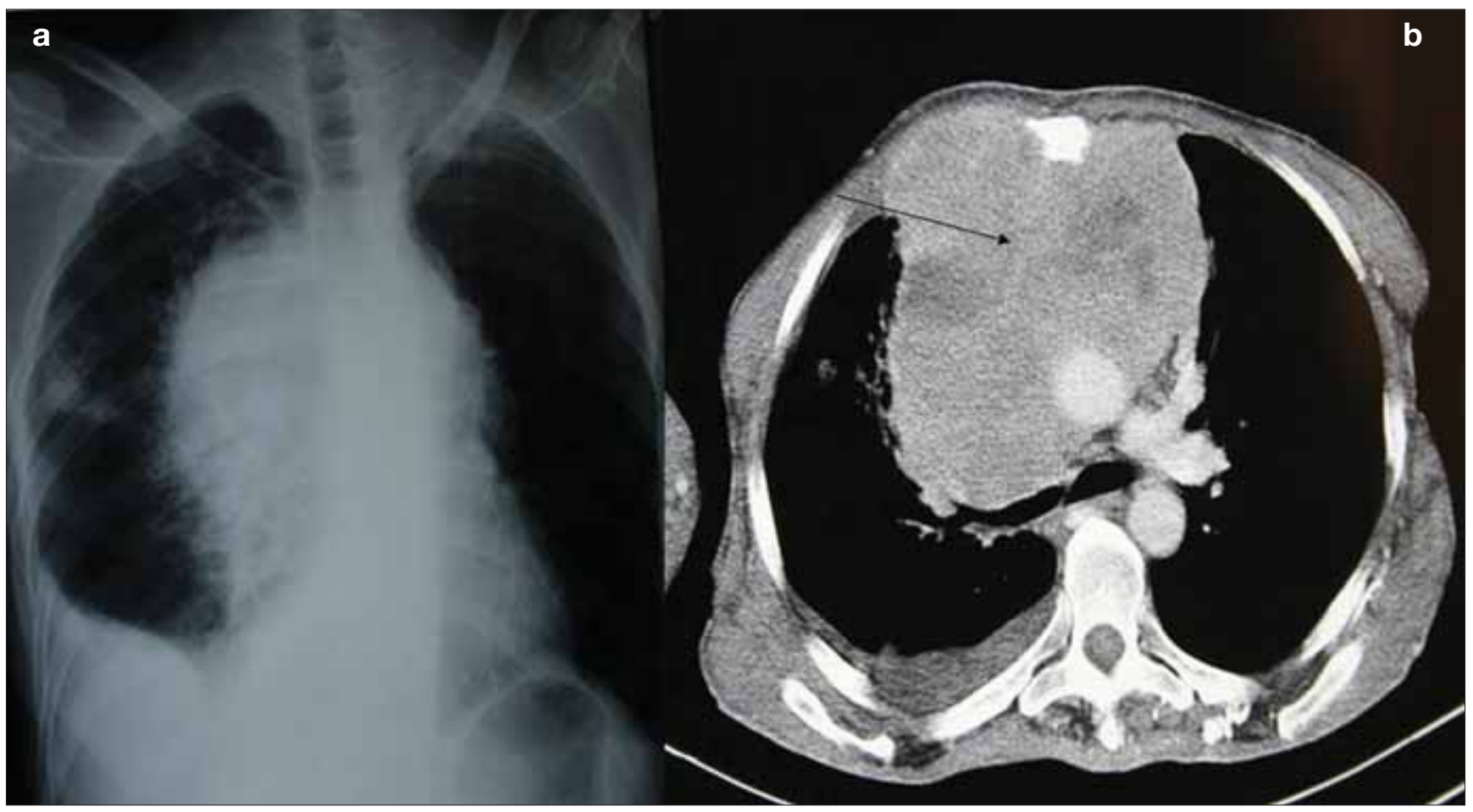

Resim 3 a, b. Non-Hodgkin lenfoma (Primer Mediastinal B- hücreli lenfoma) 


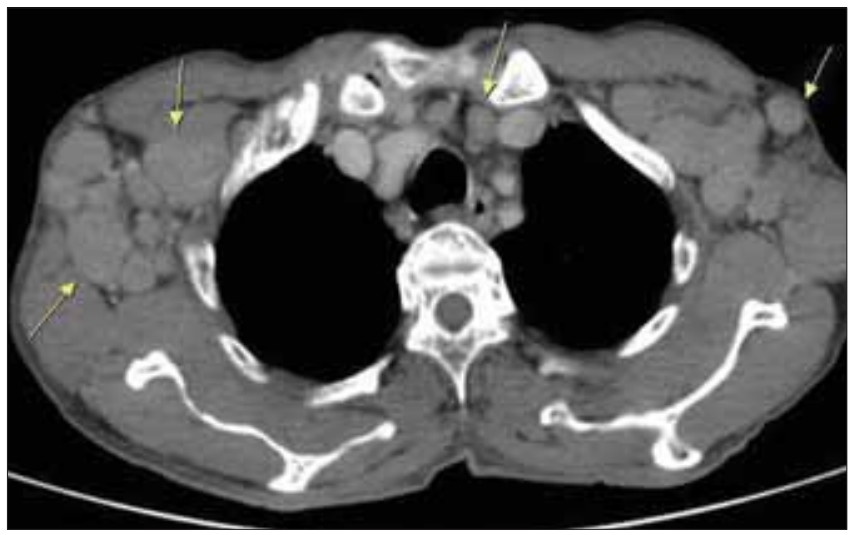

Resim 4. Mediasten ve ekstratorasik lenf nodu tutulumu (Non-hodgkin lenfoma)

Vena kava superior sendromu, radyoterapiye gerek kalmadan kemoterapiyle tedavi edilebilir (39). Kemoterapiyle \%80 komplet remisyon sağlanmıştır (38).

\section{Lenfoblastik Lenfoma}

Non-hodgkin lenfomanın nadir bir formudur, tüm NHL içinde \%1-5 arasındadır (40). En sık çocukluk yaş grubunda görülür ve çocuklarda tüm NHL lerin \%3050'sini kapsar (41). Ortalama görülme yaşı 9 civarındadır ve erkek çocuklarında daha sık görülür. Çocuk hastaların \%75'inde mediastinal kitle vardır. Çoğu hasta yaygın hastalık ile başvurur. Mediasten dışında, ekstra torasik lenf nodları, kemik iliği, santral sinir sistemi, baş ve boyun, akciğer, plevra, karaciğer, perikard, periton, cilt ve gonadlar tutulabilir (Resim 4). Lenfoblastik lenfoma akut lenfoblastik lösemi ile ilişkilidir (42). Hastada bariz kemik iliği tutulumu mevcutsa lösemi tanısı konabilir. Olağandışı olarak hastalık sadece mediastenle sınırıdır, ve tanı için biyopsi gerekir. Çoğu vakada kemik iliği biyopsisi ve periferik inceleme ile tanı konur. Lenfoblastik lenfoma hızlı büyüyen tümörlerdendir. Hızlı yayıldığından zaman kaybedilmemeli santral sinir sistemi yayılımını tespit etmek için lomber ponksiyon yapılmalıdır. Keza vakaların \%10'unda tanı anında santral sinir sistemi tutulumu mevcuttur (19).

Tedavide multiajanlarla kemoterapi yapilır. Komplet cevap oranı $\% 80$, uzun survey $\% 45$ civarındadır.

\section{KAYNAKLAR}

1. Naruke T, Suemasu K, Ishikawa S. Lymph node mapping and curability at various levels of metastasis in resected lung cancer. J Thorac Cardiovasc Surg 1978;76:832.

2. American Thoracic Society. Clinical staging of primary lung cancer. Am Rev Respir Dis 1983;127:659-64.

3. Mountain CF, Dresler CM. Regional lymph node classification for lung cancer staging. Chest 1997;111:1718-23.

4. Rusch V, Crowley JJ, Goldstraw P, et al. The IASLC Lung Cancer Staging Project: proposals for revision of the $\mathrm{N}$ descriptors in the forthcoming (7th) edition of the TNM classification for lung cancer. J Thorac Oncol 2007;2:603-12.

5. Leong SP, Cady B, Jablous DM, et al. Clinical patterns of metastasis. Cancer Metastasis Rev. 2006;25:221-32.

6. Blaszyk H, Hartmann A, Bjornsson J. Cancer of unknown primary: clinicopathologic correlations. APMIS 2003;111:1089-94.

7. Dabbs D. Immunohistology of metastatic carcinoma of unknown primary in Diagnostic Immunohistochemistry. Churchill Livingstone, second edit. 2006.

8. Sève P, Billotey C, Broussolle C, Dumontet C, Mackey JR. The role of 2-deoxy-2-f-18 fluoro-D-glucose Positron Emission Tomography in disseminated carcinoma of Unknown primary site. Cancer 2007;109:292-9.

9. iquet $\mathrm{M}$, Banu E,Foucault C. Unknown primary malignancy metastatic to thoracic lypmh nodes. In Shields TW, LoCicero J, Reed Carolyn E, Feins RH.ed General Thoracic Surgery vol 2, 7th.ed.Philadelphia: Lippincott Williams and Wilkins; 2009;1435-40.

10. Pavlidis N, Briasoulis E, Pentheroudakis G; ESMO Guidelines Working Group. Cancers of unknown primary site: ESMO Clinical Practice Guidelines for diagnosis, treatment and follow-up. Ann Oncol. 2010;5:228-31.

11. Riquet M, Badoual C, Le Pimpec Barthes F, et al. Metastatic thoracic lymph node carcinoma with unknown primary site. Ann Thorac Surg 2003;75:244-9.

12. Mahon TG, Libshitz HI. Mediastinal metastases of infradiaphragmatic malignancies. Eur $\mathrm{J}$ Radiol 1992;15:130-4.

13. Kohdono S, Ishida T, Fukuyama $\mathrm{Y}$, et al. Lymph node cancer of the mediastinal or hilar region with an unknown primary site. J Surg Oncol 1995;58:196-200.

14. Carcangiu ML, Zampi G, Pupi A, et al. Papillary carcinoma of the thyroid. A clinicopathologic study of 241 cases treated at the University of Florence, Italy. Cancer 1985;55:805-28.

15. Cho KR, Epstein Jl. Metastatic prostatic carcinoma to supradiaphragmatic lymph nodes. A clinicopathologic and immunohistochemical study. Am J Surg Pathol 1987; $11: 457-63$.

16. Duwe BV, Sterman DH, Musani Al. Tumors of the mediastinum. Chest 2005;128:2893-9.

17. Swerdlow, SH, Campo, E, Harris, NL, et al. (Eds). World Health Organization Classification of Tumours of Haematopoietic and Lymphoid Tissues, IARC Press, Lyon 2008.

18. Vardiman, JW, Thiele, J, Arber, DA, et al. The 2008 revision of the WHO classification of myeloid neoplasms and acute leukemia: rationale and important changes. Blood 2009; 114:937.

19. Smith S, Besien K. Diagnosis and Treatment of Mediastinal Lymphomas. In Shields TW, LoCicero J, Reed Carolyn E, Feins RH.ed General Thoracic Surgery vol 2, 7th.ed.Philadelphia: Lippincott Williams and Wilkins; 2009;2379-88.

20. Medeiros LJ, Greiner TC. Hodgkin's disease. Cancer 1995;75:357-69.

21. Ries, LA, Kosary, CL, Hankey, BF, et al. (Eds). SEER cancer statistics review: 1973-1994, NIH publ no. 97-2789, National Cancer Institute, Bethesda 1997. 
22. Cozen W, Katz J, Mack TM. Risk patterns of Hodgkin's disease in Los Angeles vary by cell type. Cancer Epidemiol Biomarkers Prev 1992;1:261-8.

23. Hjalgrim H, Askling J, Sorensen P, et al. Risk of Hodgkin's disease and other cancers after infectious mononucleosis. J Natl Cancer Inst 2000;92:1522-8.

24. Chang ET; Zheng T; Weir EG; Borowitz M; Mann RB; Spiegelman D; Mueller NE. Aspirin and the risk of Hodgkin's lymphoma in a population-based case-control study. J Natl Cancer Inst 2004;96:305-15.

25. Nieters A; Rohrmann S; Becker N; et al. Smoking and lymphoma risk in the European prospective investigation into cancer and nutrition. Am J Epidemiol. 2008;167:1081-9.

26. Grulich AE, Li Y, McDonald A, et al, Rates of non-AIDSdefining cancers in people with HIV infection before and after AIDS diagnosis. AIDS. 2002;16:1155-61.

27. Mahoney DH Jr, Schreuders LC, Gresik MV, McClain KL. Role of staging bone marrow examination in children with Hodgkin disease. Med Pediatr Oncol 1998;30:175-7.

28. Lister TA, Crowther D, Sutcliffe SB, et al. Report of a committee convened to discuss the evaluation and staging of patients with Hodgkin's disease: Cotswolds meeting. J Clin Oncol 1989;7:1630-6.

29. Specht L, Gray RG, Clarke MJ, Peto R. Influence of more extensive radiotherapy and adjuvant chemotherapy on long-term outcome of early-stage Hodgkin's disease: a meta-analysis of 23 randomized trials involving 3,888 patients. International Hodgkin's Disease Collaborative Group. J Clin Oncol 1998;16:830-43.

30. Cosset, JM, Henry-Amar, M, Meerwaldt, JH, et al. The EORTC trials for limited stage Hodgkin's disease. The EORTC Lymphoma Cooperative Group. Eur J Cancer 1992; 28A:1847.

31. Carde $P$; Hagenbeek $A$; Hayat $M$ et al. Clinical staging versus laparotomy and combined modality with MOPP versus ABVD in early-stage Hodgkin's disease: the $\mathrm{H} 6$ twin randomized trials from the European Organization for Research and Treatment of Cancer Lymphoma Cooperative Group. J Clin Oncol 1993;11:2258-72.

32. Olweny, CL, Ziegler, JL. Chemotherapy plus involved-field radiation in early-stage Hodgkin's disease. N E ngl J Med 2008;358:742.

33. Canellos GP, Niedzwiecki D. Long-term follow-up of Hodgkin's disease trial. N Engl J Med 2002;346:1417-8.

34. Josting A, Reiser M, Wickramanayake PD, et al. DexaBEAM: an effective regimen for cytoreduction prior to highdose chemotherapy with autologous stem cell support for patients with relapsed/refractory mantle Leuk Lymph 2000;37:185-7.

35. Tucker MA, Coleman CN, Cox RS, et al. Risk of second cancers after treatment for Hodgkin's disease-cell lymphoma. N Engl J Med 1988; 318:76-81.

36. van Besien K, Kelta M, Bahaguna P. Primary mediastinal B-cell lymphoma: a review of pathology and management. J Clin Oncol 2001;19:1855-64.

37. Jemal A, Siegel R, Ward E, et al. Cancer statistics, 2008. CA Cancer J Clin 2008;58:71-96.

38. Todeschini G, Ambrosetti A, Meneghini G, et al. Mediastinal large B-cell lymphoma with sclerosis: a clinical study of 21 patients. J Clin Oncol 1990;8:804-8.

39. Yahalom Y. Oncologic emergencies. In De Vita F, Hellman S, Rosenberg AS, eds. Cancer: Principles and Practice of Oncology. Philadelphia: Lippincott-Raven, 1997;2469-76.

40. Simon R, Durleman S, Hoppe RT, et al. The non-Hodgkin's lymphoma pathologic classification project: long term follow-up of 1153 patients with non-Hodgkin's lymphomas. Ann Intern Med 1988;109:939-45.

41. Griffith RC, Kelly DR, Nathwani BN, et al. A morphologic study of childhood lymphoma of the lymphoblastic type: the Pediatric Oncology Group experience. Cancer 1987;59:1126-31.

42. Uckun FM, Sensel MG, Sun L, et al. Biology and treatment of childhood T-lineage acute lymphoblastic leukemia. Blood 1998;91:735-46. 